\title{
Research on the Development and Application of Kindergarten Curriculum Based on Traditional Chinese Culture
}

\author{
Jinzhi Zhang \\ Rizhao Polytechnic, Rizhao, China \\ Email: mlbsabc@sina.com
}

How to cite this paper: Zhang, J. Z. (2018). Research on the Development and Application of Kindergarten Curriculum Based on Traditional Chinese Culture. Creative Education, 9, 280-284. https://doi.org/10.4236/ce.2018.92018

Received: January 17, 2017

Accepted: February 11, 2018

Published: February 14, 2018

Copyright $\odot 2018$ by author and Scientific Research Publishing Inc. This work is licensed under the Creative Commons Attribution International License (CC BY 4.0).

http://creativecommons.org/licenses/by/4.0/

\section{cc) (i) Open Access}

\begin{abstract}
Chinese traditional culture is the wisdom crystallization of the laboring people of our country in the development of history. It contains excellent education resources such as excellent classic, handicraft and folk game. Integrating traditional culture into the education stage of children, can make children experience and appreciate the excellent culture of Chinese people from an early age, help young children to establish a good moral quality, and form a fine character. Preschool period is a critical period for children's physical and mental development. Children education stage is an important part of children's acceptance of education, and it is the beginning stage of preschool education, which has important influence on children's future study and life development. Therefore, we should fully tap the education resources in Chinese traditional culture, provide the most classic and valuable content for children education, and build a good foundation for children's future development. By analyzing the classic education resources in traditional Chinese culture and current application status of traditional Chinese culture in education, this paper provides some related measures in order to promote traditional culture in children's education.
\end{abstract}

\section{Keywords}

Children, Chinese Traditional Culture, Educational Resources

\section{Introduction}

Chinese traditional culture is the fundamental of the long-term development of Chinese people, the development and inheritance of which is an important prerequisite for China's survival in the world. At the same time, the Chinese tradi- 
tional culture contains the crystallization of the collective wisdom of the laboring people of Chinese country. It is the essence of China's cultural development. However, in recent years, our country has been affected by the idea of exam-oriented education. The development and utilization of education resources in traditional culture are ignored. Many schools and parents regard exam-oriented education as the key point of education, seriously neglecting the role of traditional culture in education. Especially in children's education process, there are much less traditional cultures involved. There are many children who don't even know the specific names, dates, customs and origins of various traditional festivals, and some teenagers are not even familiar with the four great books of our country, which fully reflect the lack of traditional culture knowledge in education. Instead, many foreign festivals and foreign movies or stars are popular in China. This situation not only is bad for the development of Chinese traditional culture, but also restricts the overall healthy development of young children to some extent. Therefore, we need to develop and utilize education resources in traditional culture, and effectively infiltrate into the children's teaching in order to let young children come into contact with excellent traditional culture, develop children's learning interest and enthusiasm, and promote the sustainable and healthy development of our traditional culture.

\section{Development and Application Analysis of Education Resources in Traditional Culture}

\subsection{The Classic Education Resources in Traditional Chinese Culture}

The classical recitation is the accumulation of the excellent traditional culture in China. To carry out a series of classical readings in the teaching process of children can help children learn to grow up. With the emphasis put on traditional culture, traditional cultural classics have gradually entered into the classroom teaching of children. The development and utilization of education resources in traditional culture are also gradually enriched. Some children's schools organize children to appreciate and read and gradually formed the characteristics of the traditional Chinese children education system. For example, the national classics comprehensive theme curriculum "happy Chinese babies", edited by Zhao Wuqian, is mainly based on classics such as the three words, the thousand words, the disciples' rules and the ancient poems, skillfully integrated the culture, the word, language, history, art, performance and other elements in the order of shallow to deep learning, and realized the effective development of education resources (Wang, 2010).

The national primary and middle school experimental teaching materials on Chinese traditional culture education were issued by our people education publishing house in the year of 2016. It is the result of special research on the topic of traditional culture education in the development of the 11th five-year plan. It contains the contents of education in primary and secondary schools, and it first 
appeared the reading content in traditional Chinese characters. At the same time, some researchers have further explored the children's education resources of traditional culture classics (Liu, 2011).

\subsection{Children's Teaching Resources of Folk Art in Traditional Culture}

Folk art is produced by the masses of people in our country. It mainly aims at enriching the folk customs and beautifying the living environment, and gradually gets popular in People's Daily life (Liang, 2004). For example, the famous Nanling painting school in folk art is an important component of Lingnan culture. It is known as "Lingnan three show" together with Guangdong music and Cantonese opera.

\subsection{Children's Teaching Resources of Folk Opera in Traditional Culture}

Chinese opera is a more comprehensive art form in China. It is formed by the combination of singing, monologue, dancing and other elements. For example, the famous Cantonese opera in folk opera has profound cultural values and artistic connotation, which can be regarded as an excellent teaching resource for children. We should attach great importance to the value of children's education in folk drama (Sun, 2006).

\section{The Current Application Status of Traditional Chinese Culture in Education}

The education resources of children's traditional culture are mostly concentrated in the development and utilization of curriculum resources. However, the content and public service system of the digital construction of children's traditional culture should be further improved.

\subsection{The Content of Education Teaching Resources in Children's Traditional Culture Needs to Be Enriched}

At present, education resources of children's traditional culture are mostly multimedia presentations of course knowledge content or activities, and the quality of content is uneven. Especially the value of excellent traditional culture content in pre-school education needs to be excavated. Starting from the cognitive rules and activities of children, we need to screen out the most typical and representative excellent traditional culture articles and themes in traditional culture and organize, develop and share education resources, by combining the expectations and demands of the age and society for the growth and development of young children, following the characteristics of children's physical and mental development, and considering children's personality differences, hobbies and future developments. For example, teachers could let the children recognize the meaning of different faces by coloring or making different faces, telling stories about the Peking Opera and other ways in order to let children fall in love with Peking 
Opera which is a kind the quintessences of Chinese culture.

\subsection{The Public Service System for Children's Education Resources Needs to Be Improved}

The shortage of education funds and the uneven education hardware cause the lagging children education developments and uneven teachers' qualities. And there is a lack of effective communications and cooperations between kindergartens (Xie \& Wei, 2011).

\subsection{Technical Support Needs Urgent Attention}

Since most kindergartens belong to the marketized garden, so the kindergartens are mostly profit-oriented. Therefore, there is very little investment in the development and utilization of curriculum resources and technical support needs urgent attention. At the same time, due to the technical environment, teachers' levels, student characteristics and so on, kindergartens often encounter the bottleneck of large-scale application promotion. The present mode lacks the attention to the cognition law and characteristics of children.

\section{Measures for Application of Children's Education Resources in Traditional Culture}

\subsection{To Rationally Use the Digital Resources to Carry Out the Teaching of Children}

With the improvement of information technology, the digital learning resources in Chinese children's traditional culture are emerging gradually, which enriches the teaching mode and learning mode of kindergarten and embodies the individuality and diversity of preschool teaching. The digital resources include projectors, computers, multimedia classrooms and so on. It not only can help children to acquire the ability to build knowledge system, but also cultivate children's information literacy and problem awareness at the same time. It applies the digital resources reasonably to the children's teaching activities and better promotes children's learning of traditional cultural knowledge by high-quality resource presentation carrier and presentation form.

\subsection{Create a Good Learning Environment and Organize Children to Interact with Each Other}

Infiltrate the excellent traditional culture of our country into children's classroom activities step by step in order to let children gradually understand education content, and combine the game activities with stronger interest in order to deepen children's study and understanding of traditional culture. For example, the teacher can create some interesting little stories, little nursery rhymes and poems from the aspect of music to help children better understand and faster experience music works when organizing folk music appreciation course activities. At the same time, maintain a high degree of consistency in the rhythm and 
tone of the language in order to make it catchy and easy to learn and memorize for children, by which can improve children's learning interest and enthusiasm, and then improve the efficiency of teaching at last.

\section{Conclusion}

Chinese traditional culture is the wisdom crystallization of the laboring people of our country in the development of history. Paying special attention to the traditional Chinese culture inherits education for children can make children be influenced by excellent traditional culture from an early age, let children accept the enlightenment of traditional culture education, and build a good foundation for children's future growth and life. At the same time, it can also cultivate outstanding successors for the inheritance and development of our traditional culture and promote the sustainable and healthy development of our traditional culture. Therefore, the society and education departments should increase funding and technical supports for children's education in traditional Chinese culture.

\section{Funding}

Special topics on traditional culture and economic and social development: The education and practice research of Chinese traditional culture inherits in kindergarten. Project number: CZ1710164.

\section{References}

Liang, J. (2004). What Is Folk Art? Chinese Handicraft, No. 1, 18-20.

Liu, Q. (2011). Tap Education Resources and Inherite the Folk Culture. China Outside School Education, No. 7, 152.

Sun, H. X. (2006). Folk Opera (p. 16). Beijing: China Society Press.

Wang, K. X. (2010). The Development and Utilization of Folk Art Resources in Education. Grand Stage, No. 5, 177-178.

Xie, S. F., \& Wei, F. (2011). Research on Optimization Allocation of Education Curriculum Resources for Children in Minority Area. Shanghai Research on Education, No. 5, 44-46. 